\title{
PEDOT: PSS-MODIFIED PLATINUM MICROELECTRODES FOR MEASUREMENTS IN AQUEOUS MEDIA: EFFECT OF POLYMER SURFACE AREA ON LONG-TERM ANODIC PEAK CURRENT STABILITY
}

\author{
Abdelmohsen Benoudjit, Habibah Farhana Abdul Guthoos, \\ FARAH AIDA ARRIS AND WAN WARDATUl AMANi WaN SALIM \\ Department of Biotechnology Engineering, Faculty of Engineering, \\ International Islamic University Malaysia, Jalan Gombak, \\ 53100 Kuala Lumpur, Malaysia.
}

*Corresponding author: asalim@iium.edu.my

(Received: $30^{\text {th }}$ Aug. 2016; Accepted: $17^{\text {th }}$ April 2017; Published on-line: $1^{\text {st }}$ Dec. 2017)

\begin{abstract}
Contamination of drinking water by hazardous agents is becoming a serious global threat, so it is necessary to develop more efficient sensing technologies for applications in liquid media. The limited working lifetime of electrochemical biosensors, especially when measurements are made continuously in liquid media, remains an unsolved challenge. We studied the effect of PEDOT:PSS surface area on platinum microelectrodes with respect to electrode ability to conduct reversible ion-to-electron transduction in liquid media. Electropolymerization of 3,4ethylenedioxythiophene:poly(styrene sulfonate) EDOT:PSS to poly(3,4ethylenedioxythiophene):poly(styrene sulfonate) (PEDOT:PSS) was conducted on microplatinum electrodes 5 and $10 \mathrm{~mm}$ long using a galvanostatic mode. Cyclic voltammetry was used to determine capacitive peak current; higher peak current indicates higher redox capacitance. Field-emisison scanning-electron microscopy was used to study the surface morphology of the PEDOT:PSS transucer layer after measurement in liquid media. The anodic capacitive peak currents did not differ significantly between the two electrodes at day one $(\sim 0.20 \mathrm{~mA})$; however, peak current decreased by $\sim 20 \%$ and $\sim 80 \%$ at day six for 10 - and $-5 \mathrm{~mm}$ electrode lengths, respectively. The results imply that PEDOT:PSS surface area plays a role in transduction of PEDOT:PSS in aqueous media.
\end{abstract}

ABSTRAK: Air minuman yang dicemari agen merbahaya telah menjadi isu ancaman global yang serius, jadi aplikasi teknologi yang sesuai bagi mengesan bendasing dalam cecair adalah sangat diperlukan. Biosensor elektrokimia mempunyai kekangan jangka hidup untuk beroperasi, terutama apabila bacaan diambil secara berterusan dalam medium cecair, masalah ini tinggal bermasalah dan masih belum diselesaikan. Kami mengkaji kesan PEDOT:PSS pada permukaan kawasan di atas mikro-elektrod, keupayaan elektrod untuk menggerakkan cas ion-kepada-elektron secara terbalik secara langsung dalam medium cecair. Elektropolimer 3,4-ethylenedioxythiophene:poly(styrene sulfonate) EDOT:PSS kepada poly(3,4-ethylenedioxythiophene):poly(styrene sulfonate) (PEDOT:PSS) telah dijalankan ke atas elektrod mikroplatinum 5 dan $10 \mathrm{~mm}$ panjang dengan menggunakan mod galvanostatik. Kitaran voltametri telah digunakan untuk mendapatkan arus maksima kapasitan. Arus maksimum bermakna ketinggian redox kapasitan. Proses mikroskopi dapat mengesan elektron di kawasan-telah digunakan dalam kajian ini terhadap permukaan morfologi PEDOT:PSS pada permukaan sensor 
selepas bacaan sukatan diambil dalam medium cecair. Arus maksimum anod kapasitan tidak jauh berbeza antara kedua elektrod pada hari pertama $(\sim 0.20 \mathrm{~mA})$; tetapi, arus maksimum telah berkurangan sebanyak $\sim 20 \%$ dan $\sim 80 \%$ pada hari ke enam bagi 10 dan $5 \mathrm{~mm}$ panjang elektrod, masing-masing. Keputusan menunjukkan permukaan kawasan PEDOT:PSS memainkan peranan dalam pergerakan arus PEDOT:PSS dalam medium cecair.

KEYWORDS: PEDOT:PSS; electrochemical biosensor; anodic capacitive current; transducer; liquid media; microplatinum electrode

\section{INTRODUCTION}

The ability to evaluate food quality and freshness, as well as water quality, requires sensors that can operate in aqueous media. Most sensors available in the market are not for long-time use in aqueous media, limiting their potential [1-3]. Nowadays, the most common type of sensing technology for detection of biological agents is electrochemical biosensors, owing to their fast measurement, simple construction, low-cost fabrication, real-time measurement capability, and applicability to a wide range of sample types [4]. By definition, an electrochemical biosensor is a device for measuring the concentration of a biological analyte, with conversion of a biochemical signal to an electrical signal via an electrochemical transducer [5]. The transducer is often a conductive polymer with reversible ion-storage capacity.

Poly(3,4-ethylenedioxythiophene), abbreviated as PEDOT, is an organic conductive polymer derived from polythiophene. PEDOT can be deposited on biosensor electrodes by electropolymerization of the monomer (3,4-ethylenedioxythiophene (EDOT) in poly(styrene sulfonate) (PSS) solution, forming the water-soluble PEDOT:PSS [6]. Many studies have reported application of PEDOT:PSS in biosensor development; the PEDOT:PSS composite possesses high electrical conductivity and biocompatibility, both important key characteristics in biosensor development [7].

A challenge that remains unsolved when PEDOT:PSS is used as a transducer layer in electrochemical biosensors, is its limited working lifetime when electrical measurements are made in liquid media. PEDOT:PSS is highly hydrophilic and unstable in liquid media because of the presence of the water-soluble PSS chain [8], which has a tendency to degenerate in an aqueous medium; with time, it can be easily peeled off from the electrode surface, leading to a decrease in biosensor performance [9] and limiting PEDOT:PSS application as the transducer layer in biosensors.

Considerable research has been performed to improve the longevity in liquid media of biosensors using PEDOT:PSS. Different techniques such as dip-coating and drop-casting have been used to deposit PEDOT:PSS on the working-electrode surface; techniques of PEDOT:PSS deposition can affect the quality of the transducer layer. A binder has been utilized in the deposition techniques in order to increase adhesion of PEDOT:PSS to an electrode surface [9] [10]. To fabricate PEDOT:PSS transducers that are stable with long lifetime in liquid media, good adhesion is required between the transducer and the electrode surface. In this preliminary work, we studied the effect of the PEDOT:PSS surface area on anodic capacitive peak current. Field-emission scanning-electron microscopy (FESEM) was used to verify PEDOT:PSS adhesion to the platinum electrode surface after electrode measurement in aqueous media. 


\section{MATERIALS AND METHODS}

\subsection{Reagents and Apparatus}

3,4-ethylenedioxythiophene (EDOT), poly(sodium 4-styrene sulfonate) (NaPSS) solution, and lithium perchlorate $\left(\mathrm{LiClO}_{4}\right)$ were purchased from Sigma-Aldrich, St. Louis, $\mathrm{MO}$, USA. Potassium ferricyanide $\left(\mathrm{K}_{3} \mathrm{Fe}(\mathrm{CN})_{6}\right)$ and $0.1 \mathrm{M}$ phosphate buffered saline (PBS), pH 7.4, were purchased from R\&M Chemicals, Selangor, Malaysia. Distilled water was used throughout the experiments. Electrochemical characterizations of PEDOT:PSS as transducer material were performed using a three-electrode cell and pocketSTAT (IVIUM Technologies, Eindhoven, Netherlands).

\subsection{Electropolymerization of PEDOT:PSS on a Platinum Microelectrode ( $\mu$ PtE)}

Electropolymerization of EDOT monomer was performed under galvanostatic conditions (scan rate $100 \mu \mathrm{A} / \mathrm{s}$, current $100 \mu \mathrm{A}$, and potential $400 \mathrm{mV}$ ) using a three-

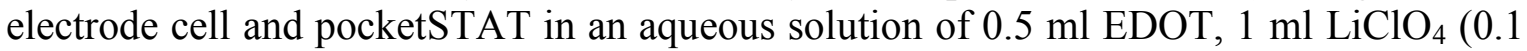
$\mathrm{M}$ ), and $1 \mathrm{ml} \mathrm{NaPSS}$ in $50 \mathrm{ml}$ distilled water. The EDOT:PSS solution was stirred for 24 hours before electropolymerization. Two $\mu \mathrm{PtEs}$, one $10-\mathrm{mm}$ long and one 5-mm long, were used; the choice of lengths was determined by availability for purchase.

\subsection{Electrochemical Characterization of $\mu$ PtE/PEDOT:PSS}

Cyclic voltammetry (CV) was performed in $0.1 \mathrm{M}$ potassium ferricyanide $\left(\mathrm{K}_{3} \mathrm{Fe}(\mathrm{CN})_{6}\right)$ at a scan rate of $100 \mu \mathrm{V} / \mathrm{s}$ to evaluate the capacitive peak current of the PEDOT:PSS transducer layer on a platinum microelectrode $(\mu \mathrm{PtE})$.

\section{RESULTS AND DISCUSSION}

\subsection{Capacitive Peak Current of PEDOT:PSS Transducer in Liquid Media}

$\mathrm{CV}$ was performed in $0.1 \mathrm{M}$ potassium ferrocyanide $\mathrm{K}_{4}\left[\mathrm{Fe}(\mathrm{CN})_{6}\right]$ solution to assess the capacitive peak current of PEDOT:PSS on $\mu$ PtEs ( $\mu$ PtE/PEDOT:PSS) $10 \mathrm{~mm}$ and 5 $\mathrm{mm}$ long for six consecutive days against a control (bare $\mu \mathrm{PtE}$ ). Figures 1 and 2 show the $\mathrm{CV}$ curves at days one, two, three, and six and Fig. 3 shows the values of anodic peak current from all days in comparison to the control.

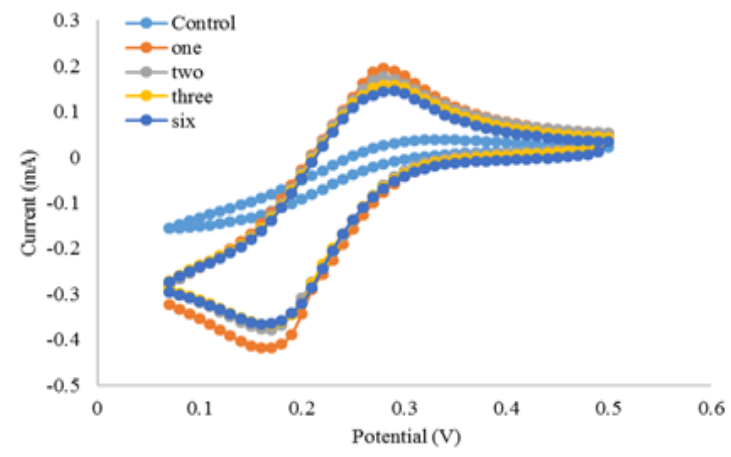

Fig. 1: CV of 10-mm $\mu$ PtE/PEDOT:PSS in $0.1 \mathrm{M} \mathrm{K}_{3} \mathrm{Fe}(\mathrm{CN})_{6}$ solution at a scan rate of $100 \mathrm{mV} / \mathrm{s}$ over six days.

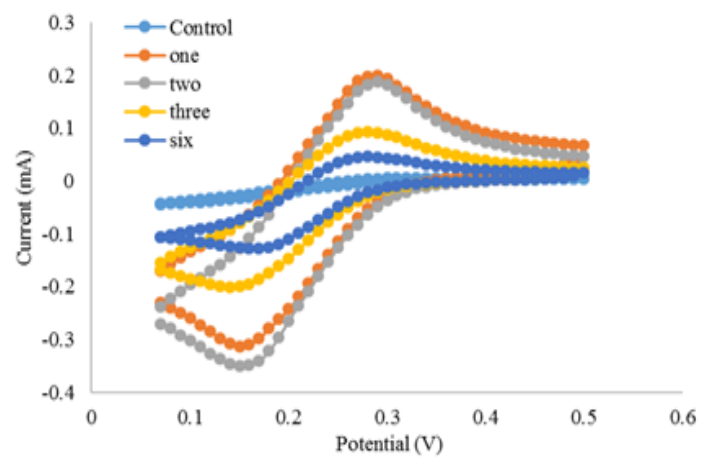

Fig. 2: CV of 5-mm $\mu$ PtE/PEDOT:PSS in $0.1 \mathrm{M} \mathrm{K}_{3} \mathrm{Fe}(\mathrm{CN})_{6}$ solution at a scan rate of $100 \mathrm{mV} / \mathrm{s}$ over six days.

The anodic capacitive peak current for both coated $\mu$ PtEs was $\sim 0.2 \mathrm{~mA}$ during the first day of measurement (day one); however, after six days the anodic peak current of the 5 - $\mathrm{mm} \mu \mathrm{PtE}$ had decreased by $\sim 80 \%$ to $0.045 \mathrm{~mA}$, while peak current for the $10-\mathrm{mm} \mu \mathrm{PtE}$ 
had decreased by only $20 \%$ (from $0.195 \mathrm{~mA}$ to $0.143 \mathrm{~mA}$ ), indicating that the $10-\mathrm{mm}$ $\mu \mathrm{PtE} / \mathrm{PEDOT}$ :PSS maintains redox activity, possibly as a result of the larger surface area that provides a stronger adhesion between PEDOT:PSS and the $\mu \mathrm{PtE}$ surface.

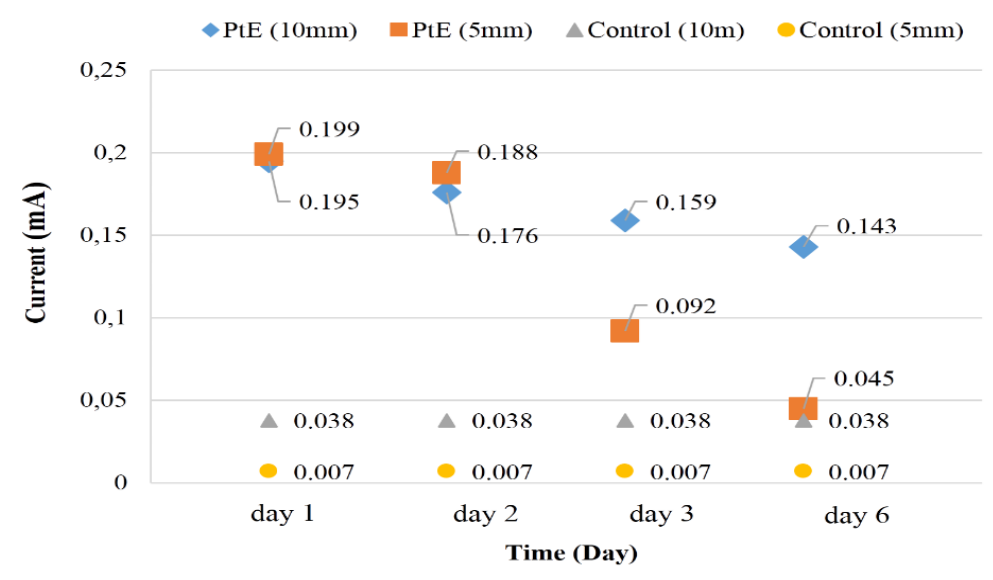

Fig. 3: Oxidation peak current versus time for 10-mm and 5-mm platinum microelectrodes.

\subsection{Surface Morphology of $\mu \mathrm{PtE} / \mathrm{PEDOT}: \mathrm{PSS}$}

Because the 10-mm electrode maintained anodic capacitive peak current with only a $20 \%$ reduction, we utilized this electrode for chronoamperometry measurements in buffer solution; most electrochemical biosensors operate in this mode. We characterized the surface of the electrode using FESEM to test the surface morphology of the electrodes after 24 hours of measurement in $0.1 \mathrm{M}$ phosphate buffered saline (PBS).
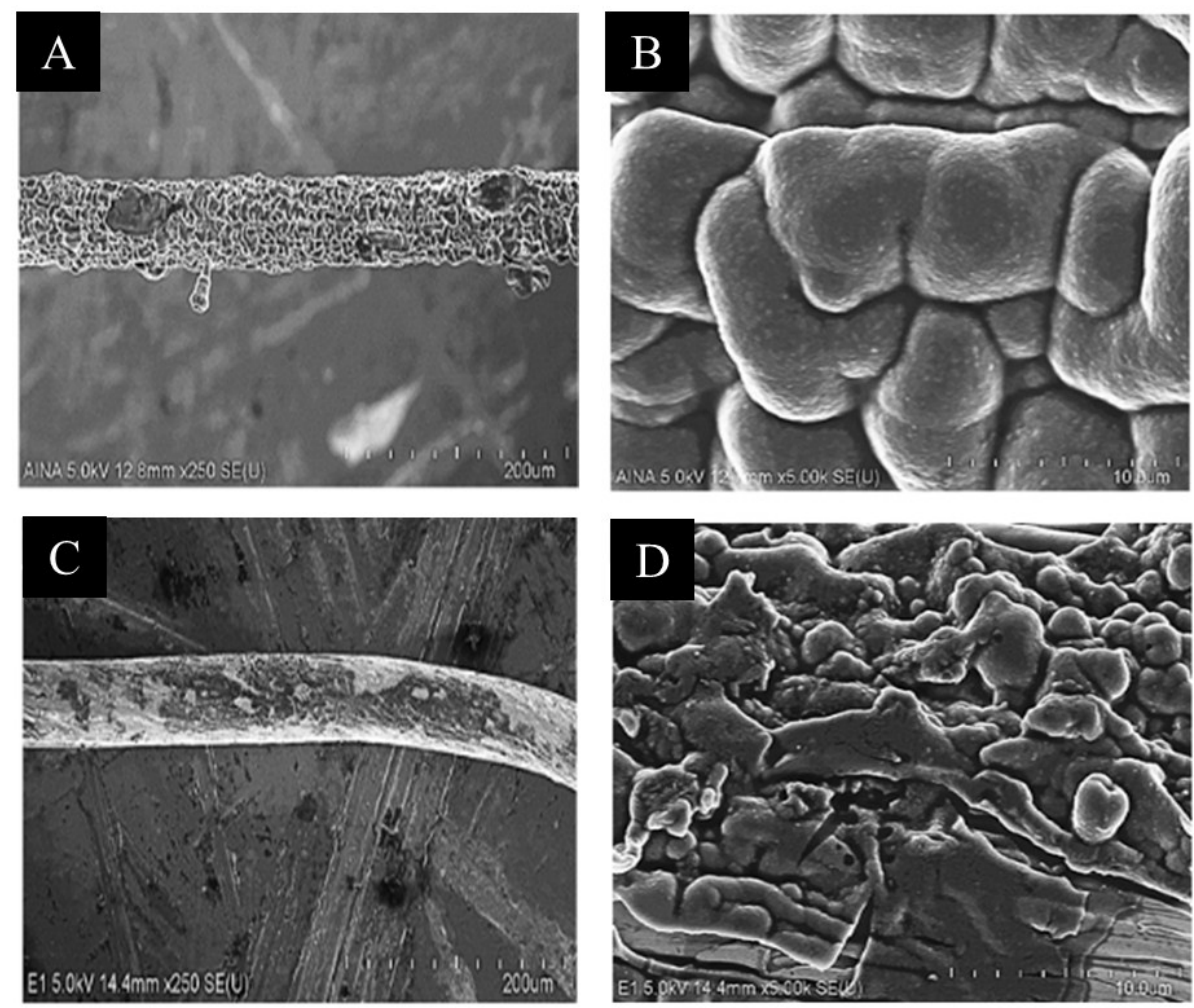

Fig. 4: FESEM images of PEDOT:PSS before (A and B) and after (C and D) chronoamperometry measurement in 0.1 M PBS, pH 7.4, for 10-mm $\mu \mathrm{PtE}$ (after 24 hours). 
Figure 4 shows FESEM images of PEDOT:PSS before and after the chronoamperometry measurement. Before measurement, the PEDOT:PSS structure on the modified $\mu \mathrm{PtE}$ was observed to be globular (Fig. 4 (A-B)), suggesting an irregular amorphous shape, common to PEDOT material. After measurement, the PEDOT:PSS structure lost the globular shape and became irregular as if ruptured as a result of prolonged measurement in liquid media (Fig 4 (C-D)). However, more studies are required on PEDOT:PSS morphology in liquid media.

\section{CONCLUSION}

PEDOT:PSS was successfully deposited on a $\mu \mathrm{PtE}$ via electropolymerization. Electrodes with larger surface area maintained anodic peak current over a period of 6 days. FESEM results imply that the structure of electropolymerized PEDOT could affect current measurement in liquid media.

\section{ACKNOWLEDGMENT}

This work was funded by the Malaysian Ministry of Higher Education (MoHE) under Fundamental Research Grant Scheme (FRGS) (Ref: FRGS/2/2014/TK04/UIAM/02/1).

\section{REFERENCES}

[1] Mello LD, Kubota LT. (2002) Review of the use of biosensors as analytical tools in the food and drink industries. Food chemistry, 77(2):237-256.

[2] Perumal V, Hashim U. (2014) Advances in biosensors: Principle, architecture and applications. Journal of Applied Biomedicine, 12(1):1-15.

[3] Amini K, Kraatz HB. (2015) Recent developments in biosensor technologies for pathogen detection in water. JSM Environ. Sci. Ecol, (3)(1):1-9.

[4] Velasco-Garcia MN, Mottram T. (2003). Biosensor technology addressing agricultural problems. Biosystems engineering, 84(1):1-12.

[5] Yogeswaran U, Chen SM. (2008) A review on the electrochemical sensors and biosensors composed of nanowires as sensing material. Sensors, 8(1):290-313.

[6] Yang X, Kirsch J, Olsen EV, Fergus JW, Simonian AL. (2013) Anti-fouling PEDOT: PSS modification on glassy carbon electrodes for continuous monitoring of tricresyl phosphate. Sensors and Actuators B: Chemical, (177): 659-667.

[7] Jiang Q, Liu C, Song H, Xu J, Mo D, Shi H, Zhu Z. (2014) Free-standing PEDOT: PSS Film as Electrode for the Electrodeposition of Bismuth Telluride and Its Thermoelectric Performance. Int. J. Electrochem. Sci, (9):7540-7551.

[8] Salim WW, Hermann AC, Zietchek M A, Pfluger JE, Park JH, ul Haque A, Porterfield DM. (2015, December) Ion-Selective Electrode Biochip for Applications in a Liquid Environment. In International Conference for Innovation in Biomedical Engineering and Life Sciences, Springer Singapore, pp. 86-93.

[9] Zhang H, Xu J, Wen Y, Wang Z, Zhang J, Ding W. (2015) Conducting poly (3, 4ethylenedioxythiophene): poly (styrene-sulfonate) film electrode with superior long-term electrode stability in water and synergistically enhanced electrocatalytic ability for application in electrochemical sensors. Synthetic Metals, (204):39-47.

[10] Wang Z, Xu J, Yao Y, Zhang L, Wen Y, Song H, Zhu D. (2014) Facile preparation of highly water-stable and flexible PEDOT: PSS organic/inorganic composite materials and their application in electrochemical sensors. Sensors and Actuators B: Chemical, (196):357-369. 